\title{
血小板濃厚液保存中のサイトカイン産生，ヒスタミン遊離 および補体の活性化
}

柴 雅之 田所 憲治 徳永 勝士 十字 猛夫
日央血液センター

(平成 6 年 4 月 26 日受付)

\section{HISTAMINE, CYTOKINE AND ANAPHYLATOXIN LEVELS IN STORED PLATELET CONCENTRATES}

M. Shiba, K. Tadokoro, K. Tokunaga and T. Juji

The Japanese Red Cross Central Blood Center

We measured the plasma levels of histamine, cytokines (IL-1 $\beta$, IL- 6 , TNF- $\alpha$, and IL-8) and anaphylatoxin (C3a) in platelet concentrates (PCs) during storage.

Increased TNF- $\alpha$ levels were found in PCs after 120 hours of storage. However, the PCs stored for 120 hours contained TNF- $\alpha$ in amounts well below those which induce fever, chills and other symptoms in most patients treated with recombinant TNF- $\alpha$.

Increased IL-8 levels were also found in stored PCs. Thus, it is important to note that a critical IL- 8 threshold might be reached in a patient upon infusion of stored PCs containing high levels of IL-8.

Plasma histamine levels were below $1 \mathrm{nmol} / 2 \mathrm{U}$ PCs after 120 hours of storage.

Anaphylatoxin (C3a and C3a-desArg) levels were increased to $56 \mu \mathrm{g} / 2 \mathrm{U}\left(1.6 \times 10^{-7} \mathrm{M}\right)$ after 72 hours of storage, a level reportedly sufficient to induce platelet activation, suppress NK activity and induce IL-1 release from macrophages.

These results may help explain some of the unexpected reactions in patients receiving PCs transfusions.

\section{1. 緒言}

輸血により発熱・莖麻疹・悪寒等の非溶血性の 副作用を認める場合がある。これらの患者の中に は輸血あるいは妊娠歴があり，それを契機に産生 された抗白血球抗体, 抗血漿蛋白抗体等が原因と 推定される例もあるが, 原因が不明なものも多い. 特に，血小板輸血において初回に非溶血性輸血副 作用（発熱）を呈する患者は $27 \%$ と比較的多く ${ }^{1)}$, このような場合には上記の抗体が原因となってい る可能性は少ないと思われれる。また一方では， これらの副作用の発症は製剤中の白血球数を減少 させることで発生頻度が低下することから，白血 球の関与は明らかとなっている.

最近, 血小板濃厚液 (PC) の保存時間と輸血副
作用の発現頻度および重篤度に関連性があり ${ }^{21}$, その原因が PC 保存中のサイトカイン産生である 可能性を示唆する報告がなされた. ま また輸血に よる発熱反応を呈した患者血清中のインターロイ キン-6 (IL-6) レベルの増大 ${ }^{4)}$ 等輸血副作用におけ るサイトカインの関与が注目されている5).これ らのサイトカインは, I）輸血による患者白血球か らの産生, II）輸血後のドナー白血球による産生, および，III）輸血前の血液保存中における産生等 が考えられている.特に, PCのように, 室温で震 盪保存する場合には保存中に白血球が発熱を誘導 するサイトカインを産生している可能性がある.

そこで今回，PC 保存中における発熱性サイト カイン6) 8)であるインターロイキン-1 $1 \beta$ (IL-1 $\beta)$, 
インターロイキン-6(IL-6), 腫瘍壊死因子(TNFa) およびインターロイキン-8 (IL-8) の産生, 白 血球崩壊による上清中のヒスタミンの遊離, およ び補体の活性化を日赤血液センターから供給され る PCを用いて調べたので報告する.

\section{2. 材料および方法}

検体は検査落ちランダム PC $(400 \mathrm{~m} l$ 採血) を用 いた。 混在する白血球数はF-800（Sysmex）を用 い測定した。

室温で震盪保存しながら，保存 $24 ， 48,72,96$, 120 時間後に $2 \sim 2.5 \mathrm{~m} l$ をサンプリングし, 血小板 および白血球を遠心分離後, 上清を $-80^{\circ} \mathrm{C} て ゙$ 凍結 保存した。

サイトカインの測定 (IL-1 $\beta$, IL-6, IL-8, TNF$\alpha$ ）は各々ELISA system (Arersham) で, ヒス タミンは RIA 法 (栄研化学), C3a および C3adesArg は RIA 法（Amersham）で測定した。
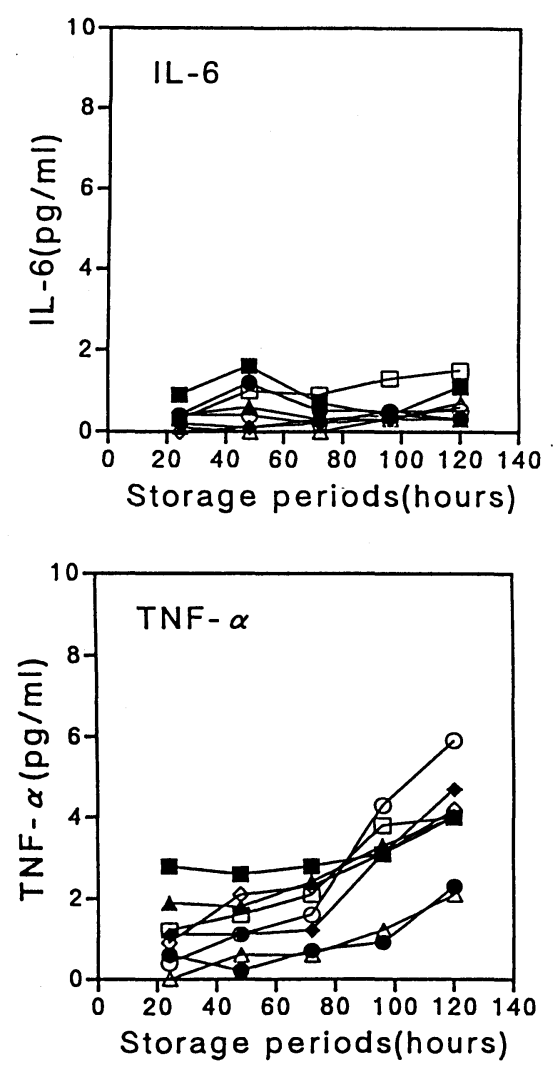

\section{3. 結 果}

3-1. サイトカイン産生

各保存時間における PC 上清中の IL- $1 \beta$, IL-6, TNF- $\alpha$, IL-8測定の結果を示した(図 1 ). TNF- $\alpha$ のみ保存 96 時間で明らかな増大を認めた（p< 0.05). しかし, そのレベルは 120 時間保存後でも $4 \mathrm{pg} / \mathrm{m} l$ という低レベルであった. IL-8は, 1 検体 のみ $(1 / 9)$ 保存 72 時間で, $110 \mathrm{pg} / \mathrm{m} l$, 保存 120 時 間で $290 \mathrm{pg} / \mathrm{m} l$ と高值を示すものが認められた。

\section{3-2. 遊離ヒスタミン}

上清中の遊離ヒスタミンの結果を図 2 に示す. 120 時間保存後でも $1 \mathrm{nmmol} / 2$ 単位以下と影響量 に至るとは考えにくいレベルであった。

\section{3-3. 補体活性化}

PC 保存中には補体系が活性化し, 保存72時間 では $56 \mu \mathrm{g} / 2$ 単位, 保存 120 時間では $72 \mu \mathrm{g} / 2$ 単位の C3a (C3a-desArg) 産生が認められた（図 3 )。こ
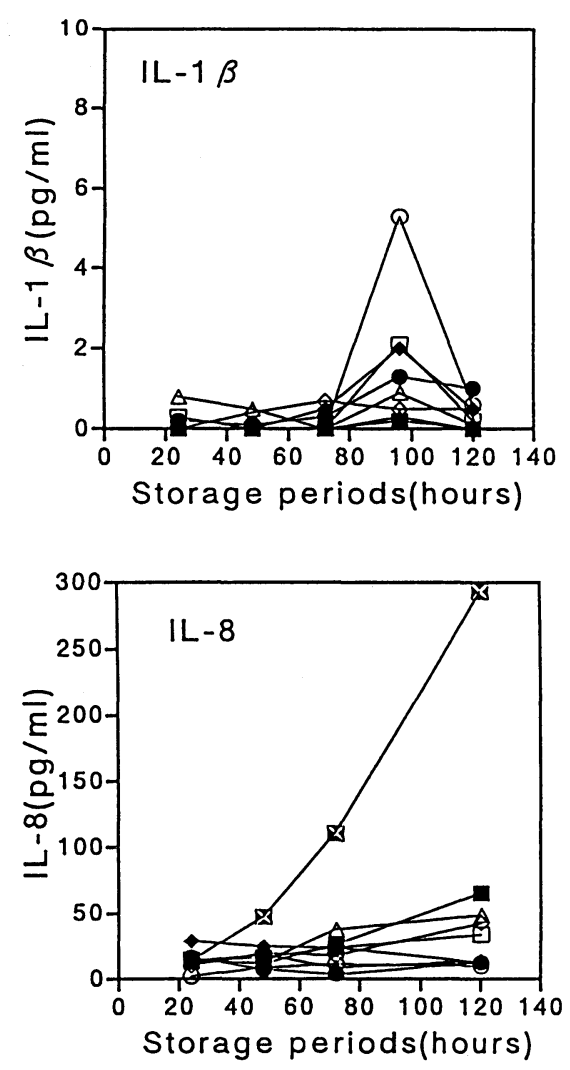

図 1 PC 保存中のサイトカイン産生 


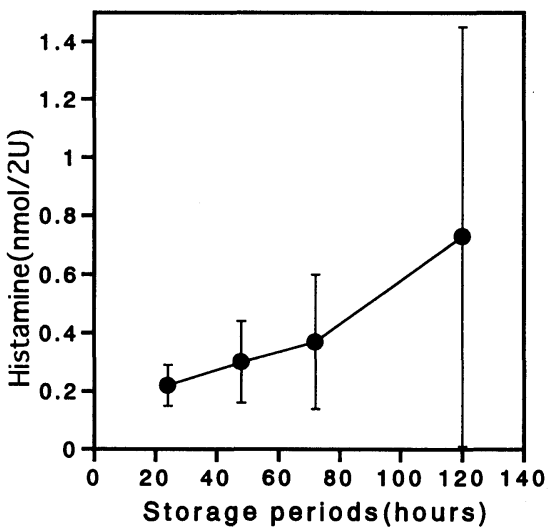

図 $2 \mathrm{PC}$ 保存中の histamine 遊離. Mean $\pm \mathrm{SD}(\mathrm{n}=$ 9)

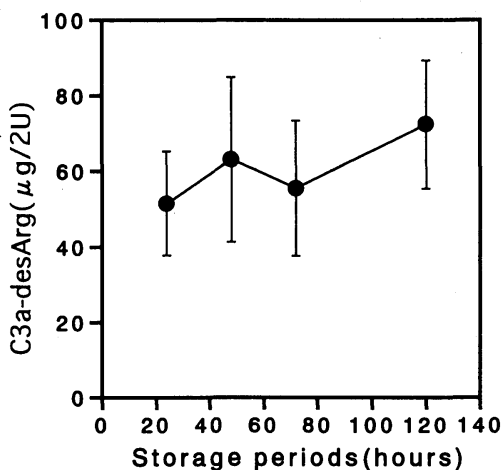

図 $3 \mathrm{PC}$ 保存中の補体活性化. Mean $\pm \mathrm{SD}(\mathrm{n}=9)$

れらは, 各々 $1.6 \times 10^{-7} \mathrm{M}, 2.0 \times 10^{-7} \mathrm{M}$ に相当する 濃度であった。

\section{4. 考 察}

保存 120 時間における TNF- $\alpha$ の産生量は $4 \mathrm{pg} /$ $\mathrm{m} l$ で, ランダム $\mathrm{PC} 2$ 単位は $40 \mathrm{~m} l$ であるからこれ は約 $160 \mathrm{pg} / 2$ 単位に相当する。一方, TNF- $\alpha$ の影 響量は $1,000 \mathrm{ng} / \mathrm{m}^{2}$ と言われている ${ }^{9}$. 従って, 今回 測定したレベルの TNF- $\alpha$ では発熱等の副作用に 直接的に関与するとは考えにくい.また, IL- $1 \beta$ お よび IL-6も保存により増大する傾向を認めた。し かし，そのレベルは TNF- $\alpha$ 以下で影響量には至 らなかった。

Muylle 等は, CPDA-1液で採血，調製した PC を保存中 (白血球数 $6 \times 10^{6} / \mathrm{m} l$ ) に発熱性サイトカ インである TNF- $\alpha$, IL- $1 \beta$, IL-6のレベルから 3
～ 5 日保存で影響量 ${ }^{9110)}\left(\mathrm{TNF}-\alpha ; 1,000 \mathrm{ng} / \mathrm{m}^{2}\right.$, IL- $1 \beta ； 1 \sim 10 \mathrm{ng} / \mathrm{kg}$ ）まで上昇し，特に，IL-6と TNF- $\alpha$ レベルと発熱性輸血副作用に関連性があ ると報告した ${ }^{3)}$. 彼らの実験では採血後， 3 日以後 に急激なサイトカインレベルの増大を認めてい る.また,これらのサイトカインの産生は PC 中か ら白血球を除去することで低下し，補体系の活性 化あるいはトロンビンにより，単球が活性化され 産生したとしている。また Stack らの検討による と好中球走化因子である IL-8を測定したところ $1,000 \mathrm{pg} / \mathrm{m} l$ 以上を示したものが 30 検体中保存 3 日で $27 \%$ ，保存 5 日で50\%と高頻度に認めてい る ${ }^{11)}$. しかし, 我々の検討では $100 \mathrm{pg} / \mathrm{m} l$ 以上の IL-8を認めたのは, 保存 3 日で 9 検体中 1 検体に のみであった。

サイトカイン産生に関する Mylleおよび Stack の報告と我々の結果が異なったのは，我々 の検討に用いた PC 中に混在した白血球数が $1.5 \times 10^{6} / \mathrm{m} l$ と, 彼らの検体に比べ白血球の混入 が少なかったためと思われた. Mylle の検討でも 白血球の混入が $3 \times 10^{6} / \mathrm{m} l$ 以下の場合にはほとん どサイトカインの産生を認めていない。さらに, エンドトキシンによってもサイトカインが誘導さ れることからコンタミネーションの可能性も否定 できない。

また欧米で用いられている CPDA-1液にはアデ ニンが添加されている，アデニンは白血球減少症 の治療薬としても使用されているので, 白血球機 能を六進し, サイトカイン産生が増大しているこ とも考えられる.今回使用した PC には MAP 採 血由来は含まれていないので，この点については 不明であり今後の検討を要する.

$\mathrm{PC}$ 中の白血球数に関しては, ランダム PC と アフェレーシス PC で異なり，また使用する機種 によっても白血球の混入数は大きく異なる，中央 血液センターのデータによると，一針法のアフェ レーシス機種である MCS (HAEMONETICS) で は $5 \times 10^{5} \sim 1 \sim 1 \times 10^{6} / \mathrm{m} l$ とランダムとほぼ同程 度白血球を混入するが，二針法の CS-3000（Baxter）では $1 \times 10^{2} / \mathrm{m} l$ と白血球の混入の極めて少な いPC が製造可能となっている．今回の検討では 
通常の輸血単位数で影響量に至るほどのサイトカ イン産生は認められなかったが，PC 中に多量の 白血球が混入した場合，発熱性のサトカインの産 生が保存中に誘導される可能性はある。この様な 場合には，輸血前の白血球除去フィルター処理で は副作用の原因物質を除去することはできないこ とになる. 従って, アフェレーシス由来の白血球 混入のより少ない PC を輸血することは，同種免 疫の防止の他に不快感・副作用を与えないと言う 意味においても有用と考えられる。

$\mathrm{PC}$ 中の遊離ヒスタミンは, 赤血球の結果と異 なり, 120 時間保存後でも $1 \mathrm{nmol} / 2$ 単位以下と影響 量に至るとは考えにくいレベルであった. Mylle らは 5 日保存 PCにおいて遊離ヒスタミンが22 $\mathrm{ng} / \mathrm{m} l(8 \mathrm{nmol} / 2$ 単位 $)$ を示す検体を認めたと報告 し12)，この様な PC を輸血した場合には輸血副作 用の原因となる可能性があることを示唆した。し かし，これも PC 中に混入した白血球数に依存し， 今回我々が検討したレベルの白血球数では遊離七 スタミンレベルは影響に達するとは思われなかっ た。

PC 保存中には補体系が活性化し，保存72時間 で，56 $\mu \mathrm{g} / 2$ 単位の C3a (C3a-desArg) 産生が認め られた。これは, $1.6 \times 10^{-7} \mathrm{M}$ に相当する濃度で あった。この補体系の活性化は白血球を除去して も，C3a の産生は抑えられないことから alternative pathwayを介していると考えられてい る ${ }^{13)}$. アナフィラトキシン活性のある C3a は血漿 中の carboxypeptidase $\mathrm{N}$ により速やかにC末 端の arginine 残基が除去され不活性型である C3a-desArg となる. C3a の測定法としては EIA 法, RIA 法が用いられているが，いずれの方法も 抗体の特異性の問題から C3a, C3a-desArg と反 応し,アナフィラトキシン活性のある $\mathrm{C} 3 \mathrm{a}$ のみを 定量的に求めることは難しい.しかしながら, C3adesArg はアナフィラトキシン活性こそ認めない が， $10^{-11} \mathrm{M}$ で血小板凝集及びセロトニン放出 ${ }^{14)}$ を，また $10^{-8} \mathrm{M}$ で単球から IL-1の産生および放出

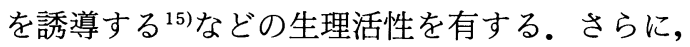
C3a-desArgにより NK 活性が抑制されるという 報告もある ${ }^{16}$. 従って, $\mathrm{PC}$ 輸血, 特に血漿量の多
いアフェレーシス PC を輸血する場合は, 多量の C3a-desArg が体内に入ることになり，免疫系へ の何らかの影響を与えている可能性もあり今後は 考慮する必要もあると思われる.

我が国においては，混入白血数も少なく，血小 板の保存期間も採血後72時間で，欧米より短いこ とからこれらのサイトカイン産生は, 欧米より少 ないと考えられた。しかしながら，白血球混入が 多い場合あるいはエンドトキシン等が混入した場 合にはサイトカインの産生も誘導されうる。この 様な場合, ベッドサイドで白血球除去フィルター 処理しても除去できないので，今後はこのような 抗原一抗体反応が関与しない機序による非溶血性 輸血副作用の発生も充分に考慮する必要があると 思われる。

\section{5. 結 語}

PC 保存中の IL- $\beta$, IL- 6, TNF- $\alpha$ および IL-8 の産生, 白血球崩壊による上清遊離ヒス夕ミン, および補体活性化を調べた。

PC 保存により発熱性サイトカイン（TNF- $\alpha$, IL-1，IL-6)の産生を認めたが，発熱等の副作用に 直接的に関与するとは考えにくいレベルであっ た。しかし，好中球走化因子である IL-8の産生を 認めた例もあり，注意が必要と思われた。

遊離ヒスタミンは, 120 時間保存後でも $1 \mathrm{nmol} / 2$ 単位以下と影響量に至るとは考えにくいレベルで あった。

アナフィラトキシン (C3a および C $3 \mathrm{a}-\operatorname{des} \mathrm{Arg}$ ) の産生は，保存 72 時間で $56 \mu \mathrm{g} / 2$ 単位 $\left(1.6 \times 10^{-7}\right.$ M）と免疫系への影響量に達するものであった。

\section{References}

1) Chambers, L.A., Kruskall, M.S., Pacini, D.G. and Donovan, L.M.: Febrile reactions after platelet transfusion : the effect of single versus multiple donors. Transfusion, 30:219-221, 1990.

2) Muylle, L., Wouters, E., De Bock, R. and Peetermans, M.E. : Reactions to platelet transfusion, the effect of storage time of the concentrate. Transfusion Medicine, 2: 289 $-293,1992$.

3) Muylle, L., Joos, M., Wouters, E., De Bock, R. and Peetermans, M.E. : Increased tumor ne- 
crosis factor a(TNF $\alpha)$, interleukin 1, and interleukin 6(IL-6)levels in the plasma of stored platelet concentrates: Relationship between TNF $\alpha$ and IL- 6 levels and febrile transfusion reactions. Transfusion, 33: 195-199, 1993.

4) Boyle, L., McLesksy, S., Freter, C. and Sacher, R.A.: High circulating interleukin-6 levels associated with acute transfusion reaction. Cause or effect? (abstract). Blood, 78(Suppl. 1) : 355a, 1991.

5) Dzik, W.H. : Is the febrile response to transfusion due to donor or recipient cytokine? (letter). Transfusion, $32: 594,1992$.

6) Okusawa, S., Gelfand, J.A., Ikejima, T., Connolly, R.J. and Dinarello, C.A.: Interleukin 1 induces a shock-like state in rabbits. Synergism with tumor necrosis factor and the effect of cyclooxygenase inhibition. J. Clin. Invest., 81 : 1162-1172, 1988.

7) Le, J. and Vilcek, J. : Interleukin $6: a$ multifunctional cytokine regulating immune reactions and the acute phase protein response. Lab. Invest., 61 : 588-602, 1989.

8) Le, J. and Vilcek, J.: Tumor necrosis factor and interleukin-1: cytokines with multiple overlapping biological activities. Lab. Invest., $56: 234-248,1987$.

9) Blick, M.B., Sherwin, S.A., Rosenblum, M.G. and Gutterman, J.U.: A phase I trial of recombinant tumor necrosis factor (rTNF) in cancer patients. Proc. Am. Soc. Clin. Oncol., 5 : $14,1986$.
10) Tewari, A., Buhles, W.C. Jr. and Starnes, H.F. Jr. : Preliminary report: effects of interleukin-1 on platelet counts. Lancet, 336 : 712-714, 1990.

11) Stack, G. and Snyder, E.L. : Cytokine generation in stored pletelet concentrates. Transfusion, 34 : 20-25, 1994.

12) Muylle, L., Laekeman, G., Herman, A.G. and Peetermans, M.E. : Histamine levels in stored platelet concentrates. Relationship to white cell count. Transfusion, 28: 226-229, 1988.

13) Schleuning, M., Schmid-Hasbeck, M., Utz, H., Jochum, M., Heim, M., Mempel, W. and Wilmanns, W.: Complement activation during storage of blood under normal blood bank conditions. Effects of proteinase inhibitors and leukocyte depletion. Blood, 79 : 3071-3075, 1992.

14) Polly, M.J. and Nachman, R.L. : Human platelet activation by $\mathrm{C} 3 \mathrm{a}$ and $\mathrm{C} 3 \mathrm{a}$ des-arg. J. Exp. Med., 158: 603-615, 1983.

15) Haeffner-Cavaillon, N., Cavaillon, J.-M., Laude, M. and Kazatchkine, M.D.: C3a(C3a des Arg) induces production and release of interleukin 1 by cultured human monocytes. J. Immunol., 139 : 794-799, 1987.

16) Charriant, C., Senik, A., Kalb, J.P. and Frade, R. : Inhibition of in vitro natural killer activity by the third component of complement: role for the C3a fragment. Proc. Natl. Acad. Sci. U.S.A., 79 : 6003-6007, 1982. 